\section{A Simple System for the Rapid Determination of the Anaerobic Compensation Point of Plant Tissue}

\author{
Jeffrey A. Leshuk and Mikal E. Saltveit, Jr. \\ Department of Vegetable Crops, Mann Laboratory, University of \\ California, Davis, CA 95616
}

Additional index words. respiration, controlled-atmosphere storage, modified-atmosphere storage, CA storage, MA storage

Abstract. A method is described for the rapid determination of the anaerobic compensation point $(\mathrm{ACP})$ of plant tissue, i.e., the $\mathrm{O}_{2}$ concentration at which $\mathrm{CO}_{2}$ production is minimum. The rate of $\mathrm{CO}_{2}$ production is measured from tissue exposed to an exponentially declining $\mathrm{O}_{2}$ concentration produced by a flow of $\mathrm{N}_{2}$ into a dilution bottle initially containing air. Too rapid a rate of $\mathrm{O}_{2}$ decline produces abnormal data because of the time required for the tissue to respond to changes in $\mathrm{O}_{2}$ concentration. The ACP is easily determined from a plot of $\mathrm{CO}_{2}$ production vs. $\mathrm{O}_{2}$ concentration. Rates of $\mathrm{CO}_{2}$ production and ACPS calculated using the exponentially declining system are similar to those calculated from traditional methods of continuously holding tissue under various $\mathrm{O}_{2}$ concentrations.

Interest in the use of thin plastic films to produce modified atmospheres in packages (Lakin, 1987; Zagory and Kader, 1988) and in the use of low- $\mathrm{O}_{2}$ atmospheres as quarantine treatments for the control of insects is high (Gaunce et al., 1982; Klag, 1985; Lidster et al., 1981; Michell et al., 1984; Soderstrom and Brandl, 1985). Successful application of these developing technologies requires detailed knowledge of the relation between the rate of respiration by the plant tissue and the gaseous atmosphere surrounding it. Of special interest is the anaerobic compensation point (ACP), which is defined as the $\mathrm{O}_{2}$ concentration at which $\mathrm{CO}_{2}$ production is minimum (Boersig et al., 1988). The ACP could indicate the lower limit for the $\mathrm{O}_{2}$ content of storage atmospheres for numerous commodities grown and stored under a wide range of conditions.

The postharvest literature contains various studies in which the ACP has been determined for some commodities (Blackman, 1928; Boersig et al., 1988; Thomas and Fidler, 1933). The traditional method of determining the ACP involves measuring the rate of $\mathrm{CO}_{2}$ production at several $\mathrm{O}_{2}$ concentrations. However, this method is time-consuming and often only approximates the true $\mathrm{ACP}$, since it must be calculated from respiration measurements taken at discrete $\mathrm{O}_{2}$ concentrations. In this paper, we describe a simple, rapid method for determining the ACP in which the $\mathrm{O}_{2}$ concentrations of the atmosphere surrounding the tissue is reduced from $20.9 \%$ to near $0 \%$. This method eliminates the need for syringe-sampling of $\mathrm{CO}_{2}$ concentrations and for preparing numerous gas mixtures, since continuous readings of

Received for publication 8 June 1989. The cost of publishing this paper was defrayed in part by the payment of page charges. Under postal regulations, this paper therefore must be hereby marked advertisement solely to indicate this fact.
$\mathrm{CO}_{2}$ production are taken during the exponential decline in $\mathrm{O}_{2}$ concentration.

The $\mathrm{O}_{2}$ concentration of the atmosphere flowing past tissue can be reduced exponentially by displacing the air in a large container with a known flow rate of $\mathrm{N}_{2}$ (Fig. 1). If the dilution container with a volume $\mathrm{V}$ is initially filled with air and $\mathrm{N}_{2}$ enters the con$60 \mathrm{~cm}$ of water to capillaries $\mathrm{R} 1$ and $\mathrm{R} 2$, respectively. tainer at a flow of $\mathrm{F}$, then the $\mathrm{O}_{2}$ concentration $\mathrm{C}$ in the outlet gas stream at any time $\mathrm{t}$ is given by the following generalized equation for a one-compartment dilution process [Simon, 1972): $C=C_{o} \mathrm{e}^{-(F / V) t}=C_{o} \mathrm{e}^{-k t}$, where $\mathrm{C}=$ concentrat $\left[\right.$ on at time $\mathrm{t} ; \mathrm{C}_{\mathrm{o}}=$ original concentration (i.e., $20.9 \% \mathrm{O}_{2}$ ); e = base of the natural $\log (2.71828 \ldots) ; \mathrm{F}=$ flow rate in $\mathrm{ml} \cdot \mathrm{min}^{-1} ; \mathrm{V}=$ volume $(\mathrm{ml}) ; \mathrm{t}$ $=$ time $(\mathrm{min})$; and $\mathrm{k}=$ constant $(\mathrm{F} / \mathrm{V})$.

This equation assumes that there is complete mixing between the incoming gas and the air in the container. Under this assumption, after one container volume of $\mathrm{N}_{2}$ has flowed into the container, only $36.8 \%$ of the original volume of air will still be in the container. The concentration of $\mathrm{O}_{2}$ remaining in the container decreases with the volume of $\mathrm{N}_{2}$ that has flowed through the container, as shown in Table 1. The equation can be used to show that the time (in minutes) required for the removal of $95 \%$ of the original concentration of $\mathrm{O}_{2}$ is three times the volume of the container (in milliliters) divided by the flow rate (in $\mathrm{ml} \cdot \mathrm{min}^{-1}$ ).

After five container volumes of $\mathrm{N}_{2}$ have flowed through the dilution container, the $\mathrm{O}_{2}$ concentration in the outlet stream would have decreased from $20.9 \%$ to $0.14 \%$. Since most plant tissues exhibit the characteristic increase in $\mathrm{CO}_{2}$ production coincident with the shift from aerobic to anaerobic respiration between $0.5 \%$ and $2 \% \mathrm{O}_{2}$, the system was initially designed to reduce the $\mathrm{O}_{2}$ concen-

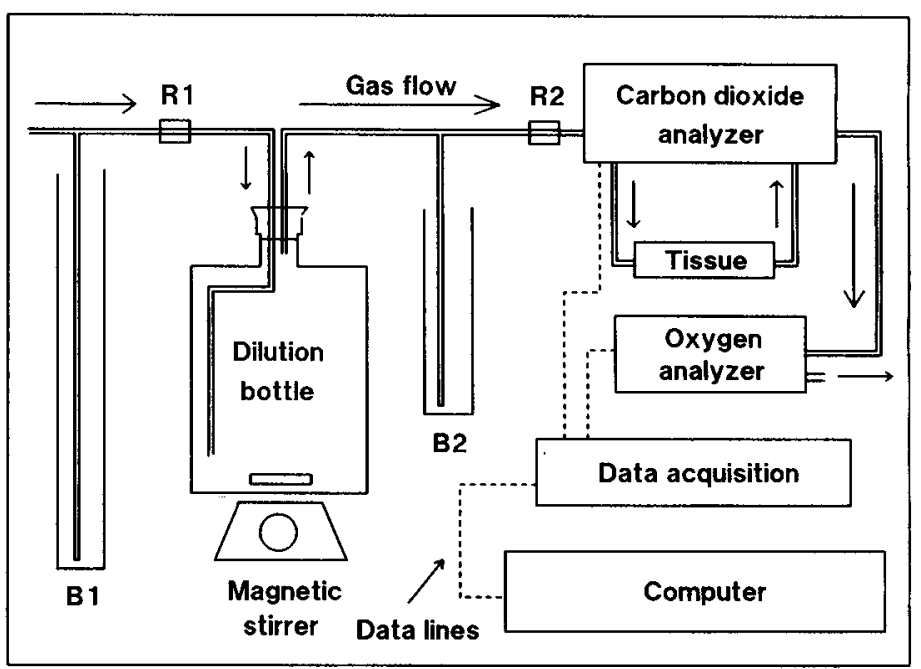

Fig. 1. Schematic of the dilution and analyzing system used to measure rates of $\mathrm{CO}_{2}$ production from carrot root disks exposed to exponentially declining $\mathrm{O}_{2}$ concentrations. The solid double lines represent tubes for gas flow, the arrows represent the direction of gas flow, and the dashed lines represent connecting wires used for data transfer. B1 and B2 are barostats to regulate gas pressures of 120 and

Table 1. Effect of the flow of $\mathrm{N}_{2}$ into a dilution bottle of air on the change in $\mathrm{O}_{2}$ concentration in the outlet gas stream. The flow of $\mathrm{N}_{2}$ is given in multiples of the volume of the dilution container.

\begin{tabular}{cccc}
\hline \hline $\begin{array}{l}\mathrm{N}_{2} \text { flow } \\
\text { (volumes) }\end{array}$ & $\begin{array}{c}\text { Air } \\
\text { removed (\%) }\end{array}$ & $\begin{array}{c}\text { Air } \\
\text { remaining (\%) }\end{array}$ & $\begin{array}{c}\mathrm{O}_{2} \\
\text { remaining (\%) }\end{array}$ \\
\hline 0 & 0.0 & 100.0 & 20.0 \\
1 & 63.2 & 36.8 & 7.4 \\
2 & 86.5 & 13.5 & 2.7 \\
3 & 95.0 & 5.0 & 1.0 \\
4 & 98.2 & 1.8 & 0.36 \\
5 & 99.3 & 0.7 & 0.14 \\
\hline
\end{tabular}




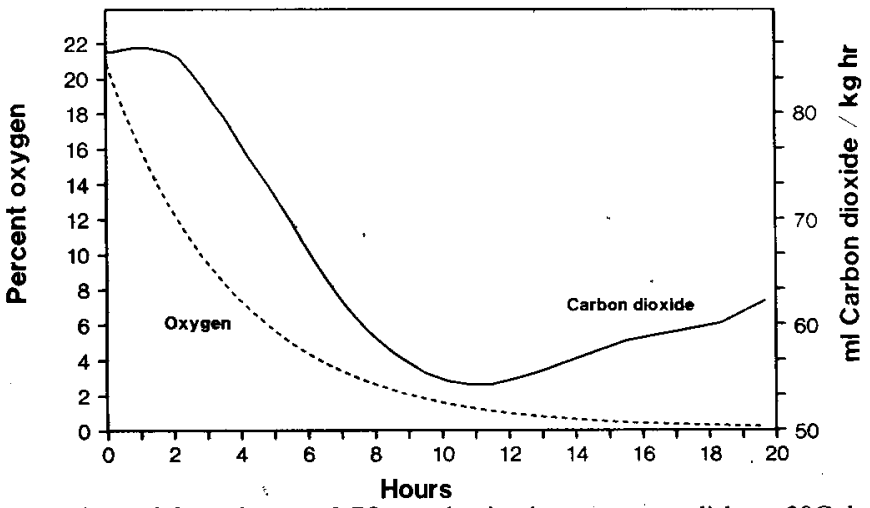

Fig. 2. Concentrations of $\mathrm{O}_{2}$ and rates of $\mathrm{CO}_{2}$ production by carrot root disks at $20 \mathrm{C}$ during a typical experiment in which the $\mathrm{O}_{2}$ concentration was reduced form $20.9 \%$ to $1 \%$ in $730 \mathrm{~min}$.

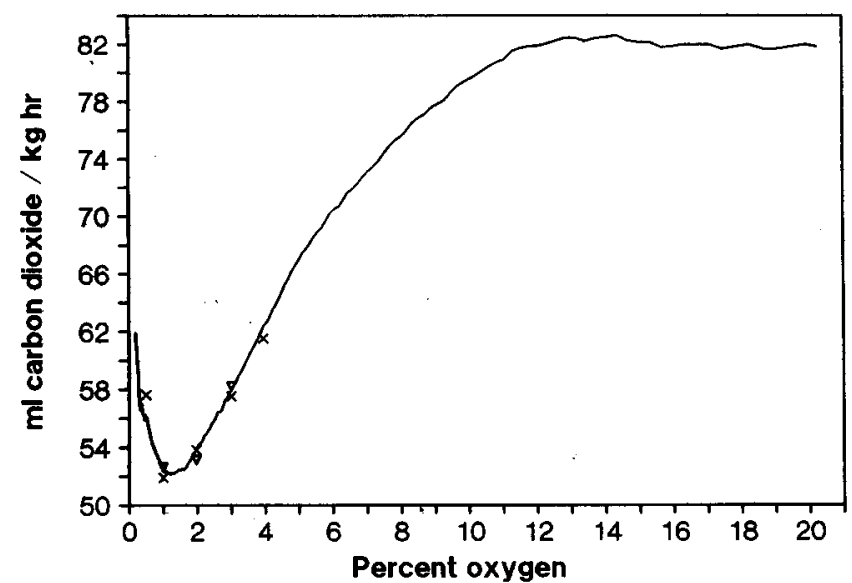

Fig. 3. Rates of $\mathrm{CO}_{2}$ production by carrot root disks exposed to distinct $\mathrm{O}_{2}$ concentrations or to exponentionally declining $\mathrm{O}_{2}$ concentrations. The smooth line was constructed from data from Fig. 2 replotted as $\mathrm{CO}_{2}$ production vs. $\mathrm{O}_{2}$ concentration. The symbols represent $\mathrm{CO}_{2}$ production from two experiments in which rates of $\mathrm{CO}_{2}$ production were measured in the traditional method during exposure of carrot root disks to the indicated $\mathrm{O}_{2}$ concentrations for $24 \mathrm{hr}$.

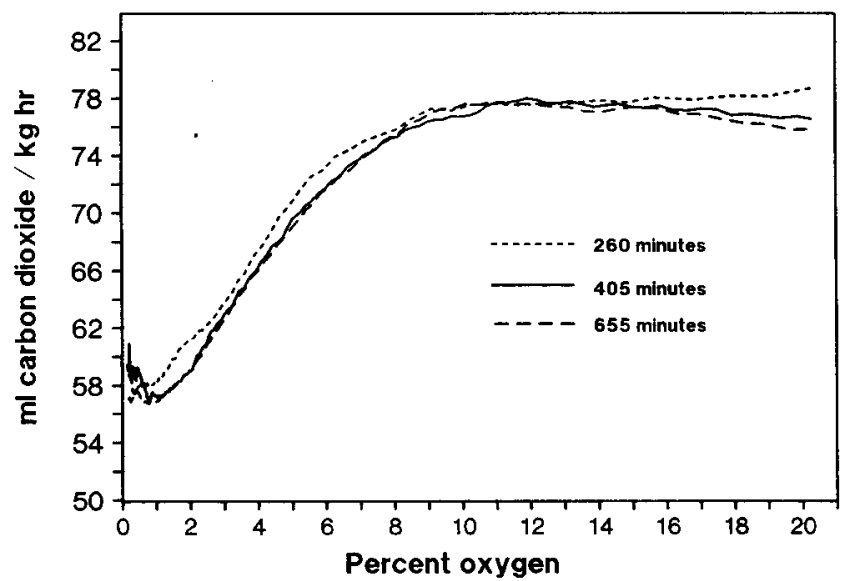

Fig. 4. Effect of three rates of decline in $\mathrm{O}_{2}$ concentration on rates of $\mathrm{CO}_{2}$ production by carrot root disks at $20 \mathrm{C}$. The time required to reduce the $\mathrm{O}_{2}$ concentration from $20.9 \%$ (air) to $1 \% \mathrm{O}_{2}$ was 260 $\min$ (dotted line), $405 \mathrm{~min}$ (solid line), or $655 \mathrm{~min}$ (dashed line).

tration from $20.9 \%$ (air) to $1 \%$ in $7 \mathrm{hr}$. Carbon, dioxide-free air in a 20 -liter jar was diluted with pure $\mathrm{N}_{2}$ at a known flow rate to create the exponentially declining $\mathrm{O}_{2}$ atmosphere. Minor adjustments to the $\mathrm{N}_{2}$ flow rate produced $1 \% \mathrm{O}_{2}$ mixtures in 4 to $11 \mathrm{hr}$. A magnetic stirring bar was used to ensure complete mixing.

A series of experiments were conducted to compare the traditional method of determining the ACP with the exponential dilu- tion method described above.

Mature carrots were obtained from a local wholesaler and held at $0 \mathrm{C}$ until used. Disks, 5 to $7 \mathrm{~mm}$ thick, were cut from the middle sections of the carrots, washed in $200 \mathrm{ppm}$ chlorine solution, rinsed in distilled water, and blotted dry. The disks were randomly sorted into 80 -g samples that were placed either in 500-ml glass jars or in glass tubes of a slightly larger diameter than the disks. A flow of $\approx 50 \mathrm{ml} \cdot \mathrm{min}^{-1}$ of humidified, eth- ylene-free air was passed through each container for $36 \mathrm{hr}$ to allow dissipation of the wounding response. The glass tubes were used for the exponentially declining $\mathrm{O}_{2}$ treatments to minimize the void volume and the delay in the change of the $\mathrm{O}_{2}$ concentration around the tissue. All experiments were run at 20C.

In one set of treatments, carrot disks were placed in jars ventilated with gas mixtures containing $0 \%, 0.5 \%, 1 \%, 2 \%, 3 \%, 4 \%$, or $21 \% \mathrm{O}_{2}\left(\right.$ balance $\mathrm{N}_{2}$ ) for 1 day. Carrots in the other set of treatments were held in an atmosphere in which the $\mathrm{O}_{2}$ concentration was reduced exponentially to $1.0 \%$ in $\approx 260$, 400 , or 655 min.

An automated gas sampling system was used to measure the concentration of $\mathrm{O}_{2}$ and $\mathrm{CO}_{2}$ in the gas flows (Fig. 1). The apparatus worked as follows. Barostat B1 controlled the pressure of $\mathrm{N}_{2}$ across-a capillary tube, $\mathrm{R} 1$, which controlled the rate of flow of $\mathrm{N}_{2}$ into the dilution bottle. A second barostat, B2, controlled the pressure of the diluted gas mixture across another capillary tube, R2, which controlled the rate of flow to the tissue. The barostats were long tubes partially filled with water. The pressures were 120 and $60 \mathrm{~cm}$ of water from barostat B1 and $\mathrm{B} 2$, respectively. The gas mixture first passed through the reference cell of the PIR-2000 infrared $\mathrm{CO}_{2}$ gas analyzer (IRGA) (Horiba Instruments, Irvine, Calif.) before flowing through the glass tube containing the carrot disks. The flow of gas from the chamber holding the carrot disks then passed through the IRGA sample cell before passing through a Model 755 paramagnetic $\mathrm{O}_{2}$ analyzer (Beckman Instruments, Fullerton, Calif.). The $\mathrm{CO}_{2}$ and $\mathrm{O}_{2}$ concentrations were measurable down to $0.001 \% \pm 0.0001 \%$ and $0.01 \% \pm$ $0.002 \%$, respectively. Switching the gas flow between mixtures with dissimilar $\mathrm{O}_{2}$ and $\mathrm{CO}_{2}$ concentrations showed that the time required for the $\mathrm{O}_{2}$ and $\mathrm{CO}_{2}$ analyzers to respond to the changes and reestablish a stable output was 45 and 5 see, respectively. Data from each instrument were collected every $5 \mathrm{~min}$ with a Hewlett-Packard model 3421A data acquisition unit controlled by a HP71B computer. Data were stored in the HP71B and later downloaded to a PC for processing. Tissue fresh weight, gas flow rates, and measured concentrations of $\mathrm{O}_{2}$ and $\mathrm{CO}_{2}$ were used to calculate respiration rates.

When the traditional method to measure the ACP was used, 1-ml gas samples were analyzed for $\mathrm{O}_{2}$ and $\mathrm{CO}_{2}$ using an apparatus described by Saltveit and Strike (1989).

The $\mathrm{O}$ dilution apparatus produced exponentially declining $\mathrm{O}_{2}$ concentrations (Fig. 2 ), as predicted by the equation. The rate of $\mathrm{CO}_{2}$ production showed a slight increase before declining with the decreasing $\mathrm{O}_{2}$ concentration. Production of $\mathrm{CO}_{2}$ started a slow increase when the $\mathrm{O}_{2}$ concentration declined below $2 \%, \approx 10 \mathrm{hr}$ after the start of the experiment.

These changes are more easily seen in a plot of $\mathrm{CO}_{2}$ production vs. $\mathrm{O}$ concentration (Fig. 3). As the $\mathrm{O}_{2}$ concentration declined exponentially from $21 \%$ to $11 \%$, a slight increase was observed in the rate of $\mathrm{CO}_{2}$ pro- 
duction. Below $11 \%$, the respiration rate declined steadily, reaching the ACP at $\approx 1.25 \% \mathrm{O}_{2}$. The rates of $\mathrm{CO}_{2}$ production calculated using the traditional method of holding carrot disks continuously under different $\mathrm{O}_{2}$ concentrations were coincident with the rates calculated using the exponentially declining $\mathrm{O}_{2}$ system (Fig. 3). However, the ACP determined from the traditional method would have been $1.0 \% \mathrm{O}_{2}$.

The rate of reduction of $\mathrm{O}_{2}$ concentration had a significant effect on the ACP (Fig. 4). A rate of dilution that produced $1 \% \mathrm{O}_{2}$ in $260 \mathrm{~min}$ did not appear to allow the tissue to adequately respond to the declining $\mathrm{O}_{2}$ concentrations. The rate of $\mathrm{CO}_{2}$ production was generally higher than from experiments in which the decline in $\mathrm{O}_{2}$ took longer, and no increase in $\mathrm{CO}_{2}$ production was observed at the lower $\mathrm{O}_{2}$ concentrations. In contrast, rates of dilution that produced $1 \% \mathrm{O}_{2}$ in $\approx 400$ to 655 min produced changes in $\mathrm{CO}_{2}$ production that were coincident.

Previous work has indicated that the ACP shifts to lower $\mathrm{O}_{2}$ concentrations upon exposure to lower $\mathrm{O}_{2}$ concentrations (Boersig et al., 1988). While the period of exposure to low $\mathrm{O}_{2}$ was different between disks held continuously under low $\mathrm{O}_{2}$ and those held in the exponentially declining $\mathrm{O}_{2}$ atmosphere, we observed no difference in the ACP (Fig. $3)$. However, if the reduction in the concentration of $\mathrm{O}_{2}$ occurred too rapidly (i.e., a reduction from air to $1 \% \mathrm{O}_{2}$ in $<300 \mathrm{~min}$ ), the response of the tissue was affected and no ACP was observed (Fig. 4). Our studies of the respiratory response of carrot disks to rapid changes in $\mathrm{O}_{2}$ concentrations indicated that two distinct responses to changes in $\mathrm{O}_{2}$ concentrations occurred; one at $\approx 10 \mathrm{~min}$ and the other at $50 \mathrm{~min}$ (unpublished data). The fast response at 10 min occurred only at $\mathrm{O}_{2}$ concentrations near the ACP, while the slower response at 50 min occurred at $\mathrm{O}_{2}$ concentrations above the ACP. These results partially explain the $\mathrm{CO}_{2}$ production data observed during very rapid reductions in $\mathrm{O}_{2}$ concentration.

The exponentially declining $\mathrm{O}_{2}$ system can be used to determine the ACP with many fewer samples and without the need for numerous gas mixtures.

\section{Literature Cited}

Blackman, F.F. 1928. Analytical studies in plant respiration: I. The respiration of senescent ripening apples. Proc. Royal Soc. London 103:412445 .

Boersig, M.R., A.A. Kader, and R.J. Romani. 1988. Aerobic-anaerobic respiratory transition in pear fruit and cultured pear fruit cells. J. Amer. Soc. Hort. Sci. 113:869-873.

Gaunce, A.P., C.V.G. Morgan, and M. Meheriuk. 1982. Control of tree fruit insects with modified atmospheres, p. 383-390. In: D.G. Richardson and M. Meberiuk (eds.). Controlled atmospheres for storage and transport of perishable agricultural commodities. Timber Press, Beaverton, Ore.

Klag, N.G. 1985. Use of CA for quarantine con- trol of insects on fresh fruits and vegetables, $\mathrm{p}$. 199-206. In: S.M. Blankenship (ed.). Controlled atmospheres for storage and transport of perishable agricultural commodities. North Carolina State Univ. Hort. Rpt. 126, Raleigh.

Lakin, W.D. 1987. Computer aided hermetic package design and shelf life prediction. J. Packaging Technol. 1:82-86.

Lidster, P.D., K.A. Sanford, and K.B. McRae. 1981. Effects of modified atmosphere storage on overwintering populations of apple rust mite and European red mite eggs. HortScience 16:328-329.

Michell, F.G., A.A. Kader, G. Crisosto, and G. Meyer. 1984. Stone fruit tolerance to high CO and low $\mathrm{O}_{2}$ atmospheres. HortScience 19:573. (Abstr.)

Saltveit, M.E., Jr., and T. Strike. 1989. A rapid method for accurately measuring oxygen concentrations in milliliter gas samples. HortScience 24:145-147.

Simon, W. 1972. Mathematical techniques for biology and medicine. Academic, New York. p. 22-28.

Soderstrom, E.L. and D.G. Brandl. 1985. Controlled atmospheres to reduce postharvest insect damage to horticultural crops, p. 199-206. In: S.M. Blankenship (ed.). Controlled atmospheres for storage and transport of perishable agricultural commodities. North Carolina State Univ. Hort. Rpt. 126, Raleigh.

Thomas, M. and J.C. Fidler. 1933. Studies in zymases. VI. Zymasis by apples in relation to O concentration. Biochem. J. 27:1629-1642.

Zagory, D. and A.A. Kader. 1988. Modified atmosphere packaging of fresh produce. Food Technol: 42(9):70-77. 